\title{
Colonization of fire-damaged trees by Ips sexdentatus (Boerner) as related to the percentage of burnt crown
}

\author{
M. Mercedes Fernández Fernández
}

Fernández Fernández, M. M. 2006: Colonization of fire-damaged trees by Ips sexdentatus (Boerner) as related to the percentage of burnt crown. - Entomol. Fennica 17: 381-386.

The aim of this study is to determine how bark beetles colonise after a wild fire. Five categories of trees were established according to the percentage of burnt crown $(0 \%, 25 \%, 50 \%, 75 \%$ and $100 \%)$ in a Pinus pinaster forest in León province that had been burnt by a wild fire in 1998. During 2000 and 2001 a study was carried out on the percentage of trees attacked in each category, the distribution of attacks on the tree trunk, crown decoloration, number of maternal galleries bored and the number of trees resisting attack. Only $20 \%$ of the trees (all of them with $0 \%$ unburnt crown) survived the attack. This study shows the capacity of Ips sexdentatus as a primary pest and recommends the removal of dead and dying trees after a wild fire before its population grows large enough to kill the remaining healthy ones.

M. M. Fernández Fernández, Área de Zoología, Dpto. Ciencias Agroforestales, ETSIIAA de Palencia, Universidad de Valladolid, Avda, Madrid, 44, edificio E, 34071 Palencia, Spain; E-mail: mffernan@agro.uva.es

Received 23 February 2005, accepted 8 December 2005

\section{Introduction}

Every year a large number of devastating forest fires occur in the Iberian Peninsula. León is the second most affected province in the Castilla and León region. After a wildfire, there is a considerable increase in the number of trees susceptible to colonisation by xylophagous insects. The risk of bark beetle attacks increases due to the decreased host resistance (Geiszler et al. 1984) and mortality of fire-injured trees (Thomas \& Age 1986, McCullough et al. 1998). Fire-damaged trees emit high concentrations of volatile terpenes that indicate reduced vigour of the host. These terpenes may attract beetles - first bark beetles and later on other secondary xylophagous insects - from outside the burned area (Muona \& Rutanen 1994).

The most frequent and economically harmful species that attacked trees in the studied wildfire area was Ips sexdentatus (Fernández \& Salgado 1999). This species transports pathogenic fungal spores (Lieutier \& Yart 1989, Lieutier et al. 1989a), mainly Ophiostoma ips and Ophiostoma brunneo-ciliatum (Lieutier et al. 1989b, Fernández et al. 2004), in the puncture pits of the mandibles and sides of the pronotum and elytra (Lévieux et al. 1991). After being attacked, the tree releases constitutive resin through the resin ducts of the phloem and xylem. This resin repels or pitches out the beetles (Christiansen et al. 1987, Långström et al. 1992, Lieutier 2002). A hyper-sensitive reaction develops where a necrotic area impregnated with resinous and phenolic compounds prevents beetle gallery construction and fungal proliferation (Berryman 1969, Wong \& Berryman 1977, Mattson et al. 1988, Raffa et al. 1985, Lieutier 1990). 
Table 1. Values for DBH, height and resinosis in the different tree categories in autumn 1999.

\begin{tabular}{llllrr}
\hline \multirow{2}{*}{$\begin{array}{l}\text { Percentage of } \\
\text { burnt crown }\end{array}$} & DBH & Height $(\mathrm{m})$ & \multicolumn{3}{l}{ Resinosis $(\%)$} \\
mean \pm S.D. & 0 & 1 & 2 \\
\hline 0 (green trees) & $28.26 \pm 3.95$ & $9.31 \pm 0.85$ & 70 & 20 & 10 \\
25 (blue trees) & $25.79 \pm 2.63$ & $9.54 \pm 0.31$ & 50 & 10 & 40 \\
50 (yellow trees) & $25.26 \pm 3.79$ & $8.83 \pm 1.13$ & 80 & 10 & 10 \\
75 (red trees) & $24.44 \pm 2.77$ & $8.34 \pm 0.60$ & 80 & 20 & 0 \\
100 (black trees) & $23.71 \pm 2.22$ & $8.38 \pm 0.13$ & 80 & 20 & 0 \\
\hline
\end{tabular}

The aim of the present study was to determine (1) how the affected trees are colonised (distribution of the attacks in the tree trunk) and (2) the relationship with the percentage of burnt crown to propose sanitary measures applicable to burnt forests and therefore slow down large-scale attacks by I. sexdentatus.

\section{Material and methods}

\subsection{Study area}

The study area is located in the Sierra del Teleno (León, NW Spain) at 1,100 m a.s.1.; it is a natural $P$. pinaster Aiton forest of ca. 11,500 ha (29TQG2984 U. T. M). Although fires occur frequently in this area, the recovery potential is high due to the almost two million seedlings/ha found after fires (Tapia et al. 1998).

The climate is Mediterranean with long harsh winters and a dry period lasting from July to the end of September (Ministerio de Agricultura 1980). Mean annual precipitation is $712 \mathrm{~mm}$ and mean annual temperature $+10^{\circ} \mathrm{C}$. An interesting feature of the local climate is the frequency of dry storms and low precipitation in spring and summer, which often cause crown fires. For example, in 1979 and 1991, 2,000 ha burned; in 1993, 400 ha, and in 1997, 700 ha (Sánchez 1990). However, the 1998 wild fire that burned over 3,000 ha was the largest recorded in the study area. It was favoured by high summer temperatures, strong winds and low precipitation especially during the three months prior to the fire (September) (Santalla et al. 2002). The fire was of medium intensity and affected the tree crowns. The study area was close to the fire perimeter; consequently, some of the trees had burnt completely and others remained partially intact.

\subsection{Field procedure}

In autumn 1999, 50 remaining resin pines were selected and classified into five categories (10 trees per category) to study the colonization by $I$. sexdentatus from spring to autumn during 2000 2001. The categories were established based on the percentage of burnt crown as follows: (1) trees with unburnt crowns (foliage 100\% intact, i.e. green trees); (2) trees with $25 \%$ burnt crown (blue trees); (3) trees with 50\% burnt crown (yellow trees); (4) trees with $75 \%$ burnt crown (red trees); (5) trees with 100\% burnt crown, but with fresh phloem on the trunk (black trees). None of the trees had previously been attacked by I. sexdentatus or other scolytids during 1999.

The DBH and height of the selected trees were measured at the beginning of the study. Trunk resinosis (a parameter used for estimating fire intensity) was also calculated and classified into three categories: 0 (no resin on the trunk), 1 (medium resinosis) and 2 (high resinosis) (Table 1).

In 2000, the percentage of attacked trees in

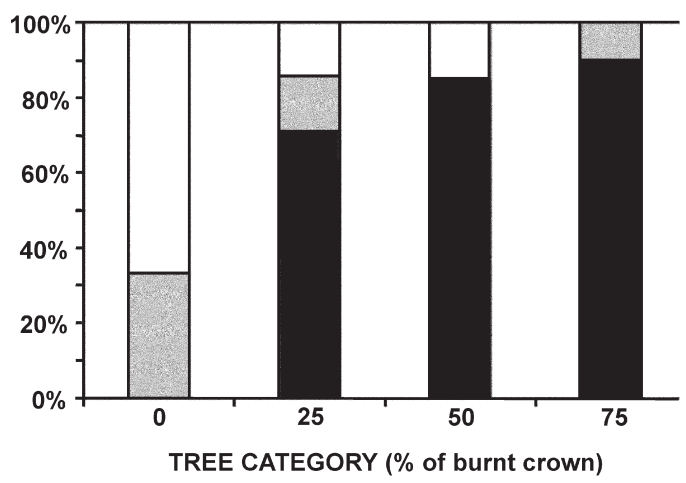

Fig. 1. Crown decoloration for each tree category in autumn 2000. White: damaged needles; grey: dry needles, and black: no needles at all. 
Table 2. Percentage of attacked trees and entrance holes detected in spring and autumn 2000, percentage of live trees in 2001 and percentage of maternal galleries bored in each tree category. $S=$ Spring, $A=$ Autumn.

\begin{tabular}{|c|c|c|c|c|c|c|c|c|c|c|c|}
\hline \multirow[t]{2}{*}{$\begin{array}{l}\% \text { trees } \\
\text { burnt crown }\end{array}$} & \multicolumn{2}{|c|}{$\begin{array}{l}\% \text { trees } \\
\text { attacked } \\
\text { in } 2000\end{array}$} & \multicolumn{6}{|c|}{ Entrance holes } & \multicolumn{2}{|c|}{$\begin{array}{l}\% \text { of trees } \\
\text { alive } \\
\text { in } 2001\end{array}$} & \multirow{2}{*}{$\begin{array}{l}\begin{array}{l}\text { Maternal } \\
\text { galleries } / \mathrm{m}^{2} \\
(\text { mean } \pm \text { S.D. })\end{array} \\
2000-2001\end{array}$} \\
\hline & $S$ & $A$ & mean $n^{0} / \mathrm{m}^{2}$ & $2 \%<1 \mathrm{~m}$ & $\%>1 \mathrm{~m}$ & mean $n^{0} / m^{2}$ & $\%<1 \mathrm{~m}$ & $\%>1 \mathrm{~m}$ & $S$ & $A$ & \\
\hline 0 (green trees) & 0 & 10 & 0 & 0 & 0 & 11.27 & 100 & 0 & 70 & 20 & $5.28 \pm 7.13$ \\
\hline 25 (blue trees) & 20 & 80 & 24.69 & 100 & 0 & 98.78 & 90 & 10 & 0 & 0 & $20.55 \pm 7.48$ \\
\hline 50 (yellow trees) & 30 & 50 & 37.82 & 100 & 0 & 63.04 & 60 & 40 & 0 & 0 & $9.33 \pm 5.45$ \\
\hline 75 (red trees) & 70 & 90 & 91.21 & 85 & 15 & 117.2 & 78 & 22 & 10 & 0 & $8.78 \pm 11.44$ \\
\hline 100 (black trees) & 20 & 50 & 26.86 & 100 & 0 & 67.16 & 100 & 0 & 0 & 0 & $9.44 \pm 5.54$ \\
\hline
\end{tabular}

each category was recorded and the number of entrance holes $/ \mathrm{m}^{2}$ detected in the first and second metre of tree trunk from the ground for both spring and autumn (Table 2). Sampling was carried out every 15 days from April to October. At the end of the field season, changes in the tree crowns were recorded for each category of tree (Fig. 1). Some of them had no needles (i.e. all had fallen off), others were dry (dry, reddish needles on the crown) or damaged (trees with more green foliage and some yellowish needles).

In spring and autumn 2001 the percentage of live trees was recorded. In October 2001, the bark was stripped and the number of maternal galler$\mathrm{ies} / \mathrm{m}^{2}$ bored in 2000 and 2001 was recorded for each tree category (Table 2).

\subsection{Statistical analyses}

Because of missing cells, it was not possible to perform a two-way Analysis of Variance (ANOVA) with interaction to test differences in the number of maternal galleries among tree categories (the five classes according to the percentage burnt crown; see above) and resinosis groups (the three classes according to degree of resinosis on tree trunks;,see above). Therefore, separate ANOVAs were used to test the differences among the tree categories and among the resinosis groups. One-way ANOVA was also used to test differences in the degree of resinosis among the tree categories. The significant results were subjected to Tukey's post hoc test for pairwise comparisons of means. Assumptions of normality and equal variances were checked prior to analyses (Sokal \& Rohlf 1996).

\section{Results}

\subsection{Percentage of attacked trees}

In spring and autumn 2000, the number of trees attacked by $I$. sexdentatus in each selected category was counted. In spring, the highest value found for the attacked trees was $70 \%$ for red trees, while the green trees showed no signs of attack. Sampling in autumn showed that $90 \%$ of the red trees and $80 \%$ of the blue trees had been attacked. As being less susceptible, only $50 \%$ of the yellow and black trees, and one green tree, had been attacked (Table 2).

The green trees were attacked in 2001. At the beginning of the sampling period (spring), three of them were dead but the other seven were still alive. In autumn, only two green trees were still alive while the others had died because of I. sexdentatus attacks during that year.

\subsection{Percentage of entrance holes and their distribution on the tree trunk}

The number of entrance holes counted in spring 2000 showed that the attacks occurred in the first metre from the ground, except for the red trees that had $15 \%$ of the holes bored in the second metre. The highest number of holes $/ \mathrm{m}^{2}$ was observed in red trees, followed respectively by yel- 
low, black and blue trees. In autumn, entrance holes were detected in the first metre of the trunk of one green tree. In the blue and yellow trees, holes were observed in the second metre from the ground, the percentage being higher in the yellow trees. The red trees had more holes in the second metre in autumn than in spring. As for the black trees, the situation was the same as in spring, that is, no entrance holes were detected in the second metre from the ground (Table 2). These trees were the most affected by fire and were subjected to heavy attacks by secondary xylophagous Coleoptera, such as Cerambycidae and Buprestidae.

In 2001, the entrance holes in the green trees could not be counted because of the low number of attacks in the very thick bark. Maternal galleries were observed in four green trees when we debarked the trees at the end of the sampling period in October 2001. However, in another one no galleries were observed.

\subsection{Percentage of live trees, and crown decoloration}

In spring 2001, sampling was carried out on green and red trees, the only ones still alive: only seven green trees and one red tree were still alive. In autumn, only two green trees were still alive (Table $2)$; the rest of the trees had died.

In autumn 2000, we noticed that the colour of the tree crowns in all four categories had changed (except for the black trees with completely burnt needles). These changes in the initial colour of the crowns were observed four months after the $I$. sexdentatus attack, when $55 \%$ of the selected trees had died (Fig. 1).

\subsection{Abundance of maternal galleries}

The number of maternal galleries counted in four of the five categories corresponds to the attacks in 2000. The final mean number of maternal galleries in the green trees corresponds to the attacks in both 2000 and 2001.

After debarking the trees, the blue trees had the highest mean number of maternal galleries $/ \mathrm{m}^{2}$, followed by the black and yellow (with similar values) and red trees; finally, the green trees had the lowest number of galleries bored (Table 2).

The number of maternal galleries in the blue trees (trees with $25 \%$ of burnt crown) was higher than in any other category (Table 2). The differences between the tree categories were significant $\left(F_{4,35}=10.12, p<0.001\right)$. However, only the blue trees differed from the other tree categories ( $p<0.02$ in all Tukey tests for the comparisons with blue trees; $p>0.32$ for the comparisons among the other tree categories).

In terms of the number of maternal galleries, no significant differences were found among the resinosis groups $\left(F_{2,37}=0.28, p=0.75\right)$. However, within the resinosis group 2 (the strongest resinosis), blue trees ( $25 \%$ burnt crown) with the highest number of maternal galleries $/ \mathrm{m}^{2}$ had the highest degree of trunk resinosis (40\%; Table 1). Correspondingly, the green trees had fewer successful maternal galleries and low resinosis.

In the degree of resinosis, no significant differences were found among the tree categories $\left(F_{4,45}=1.86, p=0.13\right)$.

\section{Discussion}

Crown scorch, foliage and bud mortality and stem damage in the bark and cambium layer all occur after a wildfire and determine whether the impacted trees survive. While complete scorch causes rapid tree death, many trees with partially scorched crowns survive. This study showed that bark beetles induce mortality in fire-injured trees primarily in the second year following fire. This pattern has also been observed by Santoro et al. (2001) in Pinus ponderosa for different species of Ips in North America, where half of the trees attacked in 1998 died in 1999, and the remainder were partly girdled by the attacks, which increases vulnerability to fires, insects and pathogens.

In our study we noticed that in spring 2001, $100 \%$ of the trees with $25 \%$ (blue trees), $50 \%$ (yellow trees) and 100\% (black trees) burnt crown had died and only $10 \%$ of those with $75 \%$ burnt crown (red trees) survived. The last red trees died six months later. The black trees died from the fire-caused damage, whereas all the trees in the other categories, regardless of the 
damage level, were attacked by bark beetles in 2000 and consequently died as a result of the beetle attack. As for the green trees, although more information is needed for 2001 on the number of attacks and their distribution, we believe that they had died as a result of $I$. sexdentatus attacks. At the end of the sampling season (October 2001) only two green trees ( $0 \%$ burnt crown) were still alive.

The blue trees, with $25 \%$ burnt crown, had the highest number of maternal galleries and also the highest value for trunk resinosis. Our study also showed that when colonization started, I. sexdentatus bored more holes in the red trees that had low trunk resinosis levels. This coincides with observations by Lieutier et al. (1988), Mattson et al. (1988) and Feeney et al. (1998) who have suggested that the resin flow is a defence reaction of a tree to fire. In our study, the highest resin flow was observed in the blue, yellow and green trees that had greater tree vitality; however, these subtle differences were not statistically significant.

At the end of the colonization period in 2000 , the red trees had suffered the highest number of $I$. sexdentatus attacks. They were the only ones with entrance holes above the first metre from the ground. This indicates that the trees with over $75 \%$ affected crowns were the most attractive for this species.

The number of maternal galleries counted at the end of 2001 showed that the blue trees (with $50 \%$ green crowns) provided the best substrate for larval development; these trees were followed by the black, yellow and red ones with statistically significant differences.

The green trees, though not directly affected by the fire, suffered post-fire drought conditions and were the last to be attacked (four of them were attacked in 2001) because of the high beetle population that developed in the other fire-injured trees. Two years after the fire, only $20 \%$ of the green trees had survived. This finding indicates that I. sexdentatus is a primary parasite capable of attacking healthy trees, as suggested by other authors (Chararas 1967, Gil \& Pajares 1986).

Based on our results, it can be deduced that all $P$. pinaster trees with $25-50 \%$ burnt crowns are the first to be attacked by I. sexdentatus and consequently die. The black trees $(100 \%$ burnt crown) are mainly used for the establishment of secondary xylophagous beetles, such as Buprestidae and Cerambycidae. The green trees $(0 \%$ burnt crown) will be attacked later on, at the phase when the population of emerging beetles is high. In Scots pine, Ehnström et al. (1995) found that most of the trees attacked by Tomicus piniperda had less than $30 \%$ green crown, while the Washington State Department of Natural Resources (2001) affirmed that approximately $40 \%$ of Pinus ponderosa pines with $50 \%$ or more crown scorch are killed by bark beetles.

We conclude that the most effective way to reduce the risk of mortality in healthy standing trees is to remove nearby dead and dying trees before the $I$. sexdentatus population grows large enough to move in and attack healthy, less injured or recovering trees.

\section{References}

Berryman, A. 1969: Response of Abies grandis to attack by Scolytus ventralis (Coleoptera, Scolytidae). Can. Entomol. 101: 1033-1041.

Chararas, C. 1967: Recherches sur l'attractivité exercée par divers conifères a l'égard d'Ips sexdentatus. Ann. Soc. Entomol. Fr. 3: 777-785.

Christiansen, E., Waring, R., \& Berryman, A. 1987: Resistance of conifers to bark beetle attack: searching for general relationships. — Forest Ecol. Manag. 22: 89106.

Ehnström, B., Långström, B. \& Hellqvist, C. 1995: Insects in burned forests-forest protection and faunal conservation (preliminary results). — Entomol. Fennica 6: 109-117.

Feeney, S., Kolb, T., Covington, W. \& Wagner, M. 1998: Influence on thinning and burning restoration treatments on presettlement ponderosa pines at the Gus Pearson Natural Area. - Can. J. Forest Res. 28: 1295-1306.

Fernández, M. \& Salgado, J. 1999: Susceptibility of firedamaged pine trees (Pinus pinaster and Pinus nigra) to attacks by Ips sexdentatus and Tomicus piniperda (Coleoptera; Scolytidae). — Entomol. Gen. 24: 105114.

Fernández, M., García, A. \& Lieutier, F. 2004: Effects of various densities of Ophiostoma ips inoculations on Pinus sylvestris in north-western Spain. - Forest Pathol. 34: 213-223.

Geiszler, D., Gara, R. \& Littke, W. 1984: Bark beetle infestations of logdepole pine Pinus contorta var murrayana following a fire in south central Oregon USA. Z. Ang. Entomol. 98: 389-394.

Gil, L. \& Pajares, J. 1986: Los escolítidos de las coníferas en la Península Ibérica. — Ministerio de Agricultura, 
Pesca y Alimentación, I. N. I. A, Madrid. 194 pp. [In Spanish.]

Långström, B., Hellqvist, C., Ericsson, A. \& Greef, D. 1992: Induced defense reaction in Scots pine following stem attacks by Tomicus piniperda L. Ecography 15: 318-327.

Lévieux, J., Cassier, P., Guillaumni, D. \& Roques, A. 1991: Structures implicated in the transportation of pathogenic fungi by the european bark beetle, Ips sexdentatus Boerner: ultrastructure of a mycangium. - Can. Entomol. 123: 245-254.

Lieutier, F. 1990: Les réactions de défense du pin sylvestre (Pinus sylvestris) contre les attaques d'insectes scolytides. - C. R. Acad. Agric. Fr. 76: 3-12.

Lieutier, F. 2002: Mechanisms of resistance in conifers and bark beetle attack strategies. - In: Wagner, M., Clancy, K., Lieutier, F. \& Paine, T. (eds), Mechanisms and development of resistance in trees to insects: 3175. Academic Publishers, Dordrecht, The Netherlands, Kluwer. 332 pp.

Lieutier, F.\& Yart, A. 1989: Preferenda thermiques des champigons associés à Ips sexdentatus Boern, et Tomicus piniperda L. (Coleoptera, Scolytidae). Ann. Forest Sci. 46: 411-415.

Lieutier, F., Yart, A., Garcia, J., Poupinel, B. \& Levieux, J. 1988: Do fungi influence the establishment of bark beetles in Scots pine?. - In: Mattson, W., Levieux, J., Bernard-Dagan, C. (eds), Mechanisms of woody plant defenses against insects: search for pattern. SpringerVerlag, New York - Berlin - Heidelberg.

Lieutier, F., Cheniclet, C. \& Garcia, J. 1989a: Comparison of the defense reaction of Pinus pinaster and Pinus sylvestris to attacks by two bark beetles (Coleoptera, Scolytidae) and their associated fungi. - Environ. Entomol. 18: 228-234.

Lieutier, F., Yart, A., Garcia, J., Ham, M., Morelet, M. \& Levieux, J. 1989b: Champignons phytopathogènes associés à deux coléoptères scolytidae du pin sylvestre (Pinus sylvestris L.) et étude préliminaire de leur agressivité envers 1'hôte. - Ann. Forest Sci. 43: 201216.

Mattson, W., Levieux, J. \& Bernard-Dagan, C. 1988: Mechanism of woody plant defense against insects. Springer-Verlag, New York.

McCullough, D., Werner, R. \& Neumann, D. 1998: Fire and insects in northern and boreal forest ecosystems of
North America. - Annu. Rev. Entomol. 43: 107-127.

Ministerio de Agricultura 1980: Caracterización agroclimática de la provincia de León. - Dirección General de Producción Agraria. Subdirección General de la Producción Vegetal. Madrid, España. 162 pp. [In Spanish.]

Muona, J. \& Rutanen, I. 1994: The short-term impact of fire on the beetle fauna in boreal coniferous forest. Ann. Zool. Fenn. 31: 109-121.

Raffa, K., Berryman, A., Simasko, J., Teal, W. \& Wong, B. 1985: Effects of gran fir monoterpenes on the fir engraver beetle, Scolytus ventralis (Coleoptera, Scolytidae), and its symbiontic fungus. - Environ. Entomol. 14: 552-556.

Sánchez, P. 1990: Selvicultura y ordenación del pino resinero (Pinus pinaster Ait.) en la sierra del Teleno (León). —-Montes 56: 69-76. [In Spanish.]

Santalla, S., Salgado, J., Calvo, L. \& Fernández, M. 2002: Changes in the Carabidae community after a large fire in a Pinus pinaster stand. - In: Trabaud, L. \& Prodon, A. (eds), Fire and Biological Processes: 215-231. Backhuys Publishers, Leiden, The Netherlands. 345 pp.

Santoro, A., Lombardero, M., Ayres, M. \& Ruel, J. 2001: Interactions between fire and bark beetles in an old growth pine forest. - Forest Ecol. Manag. 144: 245254.

Sokal, R. \& Rohlf, F. 1996: Biometry. — Freeman, San Francisco. 887 pp.

Tapia, R., Gil, L. \& Pardos, J. 1998: Los pinares (Pinus pinaster Ait.) de las estribaciones de la sierra del Teleno (León): La influencia del incendio en su ordenación. — Montes 52: 115-120. [In Spanish.]

Thomas, T. \& Age, J. 1986: Prescribed fire effects on mixed conifer forest structure at Crater Lake Oregon, USA. - Can. Entomol. 16: 1082-1087.

Washington State Department of Natural Resources 2001: Forest health alert: fire injury to trees. - Washington State Department of Natural Resources, No 01-122, U. S. A.

Wong, B. \& Berryman, A. 1977: Host resistance to the fir engraver beetle. Lesion development and containment of infection by resistant Abies grandis inoculated with Trichosporium symbioticum. — Can. J. Bot. 55: 23582365 . 